\title{
In-Service Teacher Professional Development Arrangements for Technology Integration: Some Critical Considerations
}

\author{
Muhammad Fauzan Ansyari
}

\begin{abstract}
Professional development arrangements for technology are essential for teacher capacity to improve students' achievement. Technological Pedagogical Content Knowledge (TPACK) framework which represents teachers' knowledge domains, consisting of content, pedagogy, and technology, is used in a number of professional development arrangements. This review is aimed at investigating the implementation of in-service teachers' professional development arrangements for technology integration using technological pedagogical content knowledge (TPACK) framework. In doing so, this review used five major online databases: ERIC, Web of Science, Scopus, Informaworld, and SpringerLink, with the criteria of studies addressing in-service teachers' TPACK professional development arrangements for technology integration, except for first aim since it addresses the concept of TPACK; deal with teachers teaching students without disabilities; and must be conducted between 2006 and 2012. In general, the results of this review show three different conceptualisations of TPACK model: initial model of TPACK, ICT-TPACK model, and elaborated TPACK model. Moreover, inquiry learning approach, peer-coaching, authentic learning, problem-based learning, project-based learning, and learning activity types were employed in successful TPACK professional development arrangements for in-service teachers. Finally, several conditions include engagement, authentic learning experiences, collaboration, supports, curriculum coherency, reflection, feedback, intensive training, and longer time.
\end{abstract}

Index Terms-Professional development, technology integration, technological pedagogical content knowledge (TPACK).

\section{INTRODUCTION}

Technology has greatly influenced education, and consequently, educational designers and teachers have benefitted its potential values as tools for teaching and learning. In this regard, Pineida [1] maintained that the educational uses of technology seemingly appear to be one of the teacher competencies for educational reform efforts in the $21^{\text {st }}$ century. This is because if technology is appropriately and effectively integrated, it can improve student achievement [2]. Therefore, teacher professional development arrangements on how to integrate technology into instruction or teaching become essential nowadays.

Lawless and Pellegrino [3] argue that such professional

Manuscript received March 15, 2013; revised June 28, 2013.

M. F. Ansyari is with the Faculty of Education Islamic University of Sultan Syarif Kasim Riau (UIN SUSKA Riau), Indonesia (e-mail: muhammadfauzanansyari@yahoo.com). developments are critical to ensuring that teachers keep up with changes in student performance standards, become familiar with new methods of teaching in the content areas, learn how to make the most effective instructional use of new technologies for teaching and learning, and adapt their teaching to shifting school environments and an increasingly diverse student population.

In responding to such need, this literature review was done to find out 1) teacher knowledge base for technology integration, with the objective to understand its nature and its formation, 2) different methods employed in professional development arrangements for technology integration, and 3) conditions required for success.

\section{METHODOLOGY}

This review is aimed at exploring the implementation of in-service teachers' TPACK professional development arrangements for technology integration using technological pedagogical content knowledge (TPACK) framework. The primary question of this review is "How are successful TPACK professional development programmes organised?" This main question is divided into the following subquestions:

1) What are the different conceptualisations of TPACK?

2) What are the instructional approaches used in successful TPACK professional development programmes?

3) What are the contributing factors to successful TPACK professional development programmes?

This literature review used several online databases to find relevant scientific studies or articles. In this review, five major online databases were used in searching for relevant studies: ERIC, Web of Science, Scopus, Informaworld, and SpringerLink. The criteria for the articles or studies to be selected were that 1) they must be empirical studies that addressed in-service teachers' TPACK professional development arrangements for technology integration, except for first aim since it addresses the concept of TPACK; 2) deal with teachers teaching students without disabilities; and 3) must be conducted between 2006 and 2012.

In order to answer the questions of this review, studies investigating teacher TPACK professional development programmes for technology integration were then explored to investigate the concept, the approaches to instructional methods, the factors featuring successful professional development programmes, and teachers' experience with such programmes. To easily search for relevant studies, general search terms were used, such as professional 
development (programme/arrangement), teacher learning, teacher training, or teacher education combined with TPCK TPACK, and Technological Pedagogical Content Knowledge. As a result, based on the abstract screening 91 articles were retrieved. 6 articles for question 1,13 articles for question 2, 14 articles for question 3, and 5 articles for question 4 were selected and reviewed. Finally, in the results, discussions, conclusions, and limitation parts of the studies were mainly searched and reviewed for the purposes of this review.

\section{FINDINGS: CRITICAL CONSIDERATIONS FOR TECHNOLOGY INTEGRATION PROFESSIONAL DEVELOPMENT ARRANGEMENTS}

\section{A. Teacher Knowledge Base}

One arising question on technology integration is that which framework best represents teachers' knowledge. Based on the literature, Technological Pedagogical Content Knowledge (TPACK) [4], [5] appears to a good framework for integrating technology into instruction. However, the conceptualisation of TPACK framework suggests various models which are respectively based on a variety of perspectives. Voogt, Fisser, Roblin, Tondeur, and van Braak [6] grouped these various understandings into three main categories: T(PCK) as an extended PCK, TPCK as a unique and distinct body of knowledge, and TPACK as the intersection among the three knowledge domains. The last conceptualisation as proposed by Koehler and Mishra [5] is assumed as a well-known framework for technology integration, when compared to the ICT-TPACK and the elaborated framework.

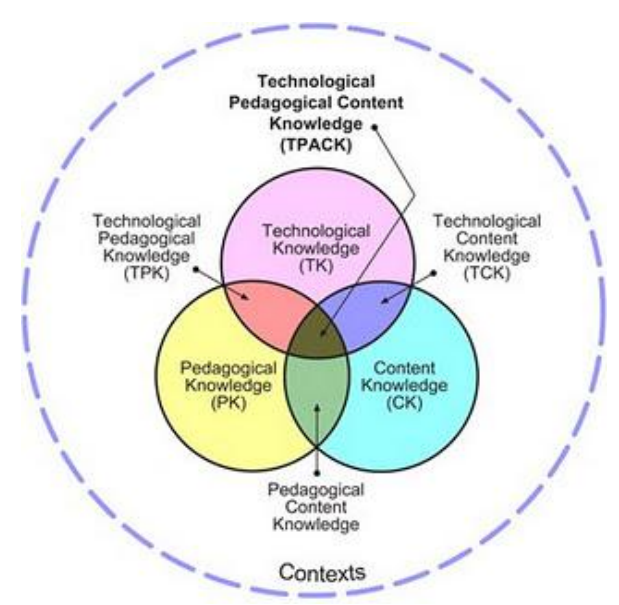

Fig. 1. TPACK framework and its knowledge components (www.tpack.org).

As depicted in the figure above, the framework has three main components: content, pedagogical, and technological knowledge. Content knowledge is teachers' knowledge and understanding of the subject matter or course being taught to students, e.g., Math, Natural Science, etc. Pedagogical knowledge is teachers' understanding of instructional approaches, methods, and classroom techniques with which teachers would be able to provide powerful learning environment. Lastly, technological knowledge refers to teachers' capacity to appropriately select and use technology that best support and promote effective instruction. This capacity allows teachers to integrate technology into their classrooms in which teachers can benefit technology for their own classroom practices. This knowledge also requires teachers' skills to operate technology they use. For example, teachers may have to be able to operate a computer and other technology devices.

These bodies of teachers' knowledge can be connected in pairs as Pedagogical Content Knowledge (PCK), Technological Content Knowledge (TCK), and Technological Pedagogical Knowledge (TPK). Pedagogical Content Knowledge refers to how teachers teach particular content-based material to students. Technological Content Knowledge is how teachers select and then use technologies to communicate particular content knowledge, while Technological Pedagogical Knowledge mainly addresses how teachers use particular technologies when they are teaching. Finally, the intersection of the three circles forms a combination of three knowledge domains, the so-called Technological Pedagogical Content Knowledge (TPCK) [4], [7].

\section{B. Approaches}

The review on the empirical research in TPACK professional development programmes for in-service teachers also shows consistent findings. In organising teacher professional development arrangements, several approaches were deemed effective. These include inquiry learning approach [8], [9], peer-coaching [10], authentic learning approach [11]-[13], project-based approach [14][17], problem-based learning approach (PBL) [18], and learning activity types [19]. Most of these approaches could help teachers develop TPACK and its knowledge domains and, in some studies, contribute to teachers' positive experiences. These instructional approaches lay on the theoretical principles of social constructivism, asserting that knowledge is constructed through social interaction and is a shared rather than an individual experience; knowledge acquisition is an adaptive function designed to organize experiences; and knowledge is the result of active mental processing by the individual in a social environment [20][22]. It is thus argued that this social constructivist theory is deemed an appropriate approach to help teachers learn to integrate technology, and is believed to stimulate deep learning and useful experiences.

\section{Conditions}

With regard to the characteristics or factors contributing to successful implementation of TPACK programmes, as revealed in this review, several critical features are suggested, including active engagement in their professional development, authentic learning experiences as to make learning meaningful for them, collaboration that can help them decrease loads and learn from one another, support, working based on the curriculum, reflection, feedback on performance, intensive training, and longer time. In supports of these findings, Lawless and Pellegrino also supported these consideration by stating that professional development programmes are usually organised in a longer duration, to provide access to new technologies for teaching and learning, to actively engage teachers in meaningful and relevant activities for their individual contexts, to promote 
peer collaboration and community building, and to possess a clearly articulated and a common vision for student achievement [3], [23]. In addition, for English language teaching setting, Richards and Farrell [24] also indicated that teacher development serves a longer-term goal and seeks to facilitate growth of teachers' understanding of teaching and of themselves as teachers. With regard to collaborative learning, Darling-Hammond [25] emphasised that teachers learn best if they study, do, and reflect; if they collaborate with other teachers; if they look closely at students and their work; and if they share what they see. This indicates that teachers should be provided with a collaborative environment for authentic learning that promotes and encourages them to practice it in real classrooms.

Therefore, successful TPACK professional development programmes can be premised on principles of effective professional development as follows.

Technology integration into instruction needs a workable framework, providing teachers with a clear formulation on how to integrate technology; therefore, TPACK as a framework suggested by Koehler and Mishra [4], [5] is deemed appropriate for such purpose.

In-service teachers' experiences are highly valued and benefitted; therefore, constructivist approach to teacher learning can be adopted to provide meaningful learning for in-service teachers.

Teachers' engagement, authentic learning experiences, and collaboration should be encouraged during the professional development programmes.

While acknowledging those above-stated guidelines, support, and working based on the curriculum need, reflection, feedback on performance, intensive training, and longer time should also be taken into account as to strengthen in-service teacher learning and performance.

\section{LimitATiON OF THE STUDY}

This literature review is written from several research findings on the implementation of TPACK professional development arrangements based on a number of research approaches. This review is an empirical finding derived from a number of selected studies; however, not all studies related to this discussion could be retrieved and analysed due to the author's limited accessibility to the articles.

This review also does not distinguish between different implementations of TPACK programmes for teachers in different context. Most of the studies cited in this review were conducted in Europe and US, only two studies were done in Asian context (studies by [10], [18]. In addition, this review also does not focus on the implementation of TPACK programmes for a specific subject matter, such as science or English. Therefore, this review finding is difficult to generalise to certain contexts because different contexts might have different characteristics and values.

This review thus needs further elaboration and studies to better understand the issues of TPACK professional development arrangements, particularly studies focusing in a certain context and in a certain subject. Despite these limitations, this current review at least gives a general overview of in-service teachers' TPACK programmes, but this review should not be considered as more or less scientific but rather as a portfolio that can help create insight into the concept of TPACK and its practical implementation for in-service teachers. Finally, the results of this review could serve as a basis for future studies to enrich our knowledge and understanding about these variables.

\section{ACKNOWLEDGEMENT}

The author thanks very much to Dr. Joke Voogt and three anonymous reviewers for their critical comments, ideas, and suggestions for the improvement of this article.

\section{REFERENCES}

[1] F. O. Pineida, "Competencies for the 21st century: integrating ICT to life, school and economical development," Procedia - Social and Behavioral Sciences, 2011, vol. 28, pp. 54-57.

[2] B. Bos, "The effect of Texas Instrument InterActive instructional environment on the mathematical achievement of eleventh grade low achieving students," Journal of Educational Computing Research, 2007, vol. 37, no. 4, pp. 350-368.

[3] K. A. Lawless and J. W. Pellegrino, "Professional development in integrating technology into teaching and learning: knowns, unknowns, and ways to pursue better questions and answer," Review of Educational Research, 2007, vol. 77, no. 4, pp. 575-614.

[4] P. Mishra and M. J. Koehler, "Technological pedagogical content knowledge: a framework for teacher knowledge," Teachers College Record, 2006, vol. 108, no. 6, pp. 1017-1054.

[5] M. J. Koehler and P. Mishra, "Introducing technological pedagogical content knowledge," in Handbook of technological pedagogical content knowledge (TPCK) for educators, A.C.o.I.a. Technology, Editor 2008, New York, NY: Routledge.

[6] J. Voogt et al., "Technological pedagogical content knowledge - a review of the literature," Journal of Computer Assisted Learning, 2012.

[7] M. J. Koehler and P. Mishra, "What happens when teachers design educational technology? the development of Technological Pedagogical Content Knowledge," Journal of Educational Computing Research, 2005, vol. 32, no. 2, pp. 131-152.

[8] A. Doering et al., "Using the technological, pedagogical, and content knowledge framework to design online learning environments and professional development," Journal of Educational Computing Research, 2009, vol. 41, no. 3, pp. 319-346.

[9] S. S. Guzey and G. H. Roehrig, "Teaching science with technology: case studies of science teachers' development of technology, pedagogy, and content knowledge," Contemporary Issues in Technology and Teacher Education, 2009, vol. 9, no. 1, pp. 25-45.

[10] S. J. Jang, "Integrating the interactive whiteboard and peer coaching to develop the TPACK of secondary science teachers," Computers and Education, 2010, vol. 55, no. 4, pp. 1744-1751.

[11] A. Jimoyiannis, "Designing and implementing an integrated technological pedagogical science knowledge framework for science teachers professional development," Computers and Education, 2010. vol. 55, no. 3, pp. 1259-1269.

[12] A. Jimoyiannis, P. Tsiotakis, and D. Roussinos, "Pedagogical and instructional design issues towards the integration of Web 2.0 tools in instruction-Implications of teachers' training pilot courses in Greece," in Proc. 7th International Conference on Next Generation Web Services Practices, 2011.

[13] H. Nicholas and W. Ng, "Factors influencing the uptake of a mechatronics curriculum initiative in five Australian secondary schools," International Journal of Technology and Design Education, 2012, vol. 22, no. 1, pp. 65-90.

[14] J. M. Blocher et al., Contextually based professional development. Computers in the Schools, 2011, vol. 28, no. 2, pp. 158-169.

[15] W. C. Allan et al., "EcoScienceWorks: teacher professional development through a collaborative curriculum project-an example of TPACK in Maine," TechTrends, 2010, vol. 54, no. 6, pp. 36-43.

[16] N. M. Trautmann and J. G. MaKinster, "Flexibly adaptive professional development in support of teaching science with geospatial technology," Journal of Science Teacher Education, 2010, vol. 21 , no. 3 , pp. 351-370.

[17] D. Polly, "Teachers' learning while constructing technology-based instructional resources," British Journal of Educational Technology, 2011, vol. 42, no. 6, pp. 950-961. 
[18] M. Y. Tee and S. S. Lee, "From socialisation to internalisation: cultivating technological pedagogical content knowledge through problem-based learning," Australasian Journal of Educational Technology, 2011, vol. 27, no. 1, pp. 89-104.

[19] J. B. Harris and M. J. Hofer, "Technological Pedagogical Content Knowledge (TPACK) in action: a descriptive study of secondary teachers' curriculum-based, technology-related instructional planning," Journal of Research on Technology in Education, 2011. vol. 43, no. 3, pp. 211-229.

[20] R. S. Prawat, "Constructivism, modern and postmodern," Educational Psychologist, 1996, vol. 31, pp. 215-225.

[21] R. S. Prawat and R. E. Floden, "Philosophical perspectives on constructivist views of learning," Educational Psychology, 1994. vol. 29, no. 1, pp. 37-48.

[22] L. S. Vygotsky, Mind in society: The development of higher psychological process, Cambridge, MA: Harvard University Press, 1978.

[23] A. Todorova and T. Osburg, "Professional development program for technology integration: facilitators and barriers to sustainable implementation," Literacy Information and Computer Education Journal (LICEJ), 2010, vol. 1, no. 1, pp. 59-66.
[24] J. C. Richards and T. S. C. Farrell, Professional development for language teachers, New York: Cambridge University Press, 2005

[25] L. D. Hammond, Teacher learning that supports student learning, in Contemporary Issues in Curriculum, A. Ornstein, L. S. BeharHorenstein, and E. Pajak, Ed., Boston, MA: Pearson Education, Inc., pp. 277-282, 2003

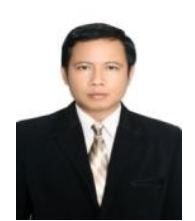

M. F. Ansyari obtained his BA in English Language Education from IAIN SUSQA Pekanbaru Indonesia in 2003, and his MSc. in Educational Science and Technology (Curriculum, Instruction, and Media Application) from University of Twente., the Netherlands in 2012.

$\mathrm{He}$ is currently a lecturer at the Faculty of Education State Islamic University of Sultan Syarif Kasim Riau Indonesia. He also works as an educational designer, consultant, and teacher trainer in several schools. His research interests include teacher professional development, technology integration in education, curriculum and media design, and Teaching English as a Foreign Language (TEFL) 